\title{
Recent progress in research on cell-to-cell movement of rice viruses
}

\author{
Akihiro Hiraguri ${ }^{1}$, Osamu Netsu ${ }^{2}$, Nobumitsu Sasaki ${ }^{3}$, Hiroshi Nyunoya ${ }^{3}$ and Takahide Sasaya ${ }^{4}$ * \\ ${ }^{1}$ Department of Applied Biological Chemistry, Graduate School of Agricultural and Life Sciences, The University of Tokyo, Tokyo, Japan \\ ${ }^{2}$ Department of Agricultural and Environmental Biology, Graduate School of Agricultural and Life Sciences, The University of Tokyo, Tokyo, Japan \\ ${ }^{3}$ Gene Research Center, Tokyo University of Agriculture and Technology, Fuchu, Tokyo, Japan \\ ${ }^{4}$ Plant Disease Group, Agro-Environment Research Division, Kyushu Okinawa Agricultural Research Center, National Agriculture and Food Research \\ Organization, Koshi, Kumamoto, Japan
}

\section{Edited by:}

Nobuhiro Suzuki, Okayama University, Japan

\section{Reviewed by:}

Carmen Hernandez, Consejo Superior de Investigaciones Científicas, Spain Nobuhiro Suzuki, Okayama University, Japan

\section{*Correspondence:}

Takahide Sasaya, Plant Disease Group, Agro-Environment Research Division, Kyushu Okinawa Agricultural Research Center, National Agriculture and Food Research Organization, 2421 Suya, Koshi, Kumamoto 861-1192, Japan e-mail: tsasaya@affrc.go.jp
To adapt to plants as hosts, plant viruses have evolutionally needed the capacity to modify the host plasmodesmata (PD) that connect adjacent cells. Plant viruses have acquired one or more genes that encode movement proteins (MPs), which facilitate the cell-tocell movement of infectious virus entities through PD to adjacent cells. Because of the diversity in their genome organization and in their coding sequences, rice viruses may each have a distinct cell-to-cell movement strategy. The complexity of their unusual genome organizations and replication strategies has so far hampered reverse genetic research on their genome in efforts to investigate virally encoded proteins that are involved in viral movement. However, the MP of a particular virus can complement defects in cell-to-cell movement of other distantly related or even unrelated viruses. Trans-complementation experiments using a combination of a movement-defective virus and viral proteins of interest to identify MPs of several rice viruses have recently been successful. In this article, we reviewed recent research that has advanced our understanding of cell-to-cell movement of rice viruses.

\section{Keywords: cell-to-cell movement, movement protein, rice, rice virus, trans-complementation experiment}

\section{INTRODUCTION}

To transport their genome from an initially infected cell to neighboring cells, plant viruses need to pass through cytoplasmic channels, called plasmodesmata (PD) in rigid cell walls. Since the diameter of PD is smaller than virus particles, most plant viruses encode one or more movement proteins (MPs) that can localize at the PD and modify the structure of PD to allow passage of the virus particles into the next cells. During the processes involved in viral cell-to-cell movement, viral MPs would be associated with virus particles or viral RNA-protein complexes (vRNPs) to and through PD (Melcher, 1990; Oparka et al., 1997; Waigmann et al., 2004; Lucas, 2006; Benitez-Alfonso et al., 2010).

The first evidence suggesting that cell-to-cell movement for a certain plant virus is controlled by a viral MP was provided by a study on a $30-\mathrm{kDa}$ protein of a temperature-sensitive mutant of tobacco mosaic virus (TMV) that replicates but is defective in movement at certain temperatures (Meshi et al., 1987). In reciprocal experiments using the infectious TMV mutants, wild-type TMV was blocked in the cell-to-cell movement when the TMV gene for the wild-type $30-\mathrm{kDa}$ protein was replaced by the mutant protein. Furthermore, viral movement was completely lost when a frameshift mutation was introduced into the translation start codon of the gene for the $30-\mathrm{kDa}$ protein. This research indicated that the $30-\mathrm{kDa}$ protein is responsible for movement of the virus. These studies gave rise to similar ones on many other plant viruses, and it soon became clear that MPs are general features for both plant RNA and DNA viruses in different genera (Atabekov and
Dorokhov, 1984; Waigmann et al., 2004; Lucas, 2006; Taliansky et al., 2008).

Over 15 viruses affect rice (Oryza sativa L.), one of the most important cereal crops for nearly half of the world's population, and 12 are very destructive in the major rice-producing regions, especially in Asia (Hibino, 1996). These viruses are transmitted by planthoppers, leafhoppers, and chrysomelid beetles in a persistent or semi-persistent manner, or by soil-inhabiting fungus. Although the majority of plant viruses are positive-sense RNA viruses, rice viruses encompass many types of viruses, e.g., double-stranded RNA viruses [rice black-streaked dwarf virus (RBSDV) and rice dwarf virus (RDV)], segmented negativesense RNA viruses [rice stripe virus (RSV) and rice grassy stunt virus (RGSV)], a non-segmented negative-sense RNA virus [rice transitory yellowing virus (RTYV)], a segmented positive-sense RNA viruses [rice stripe necrosis virus (RSNV) and rice necrosis mosaic virus (RNMV)], non-segmented positive-sense RNA viruses [rice yellow mottle virus (RYMV) and rice tungro spherical virus (RTSV)], and a double-stranded DNA virus [rice tungro bacilliform virus (RTBV)].

The viral MPs are involved with viral movement without affecting virus replication in single cells. In addition, even though viral MPs can be genetically swapped between different viruses, the exchangeability and complementation of movement functions have been conserved for many plant viral MPs with viruses of different families and even with plant and insect viruses (Solovyev et al., 1996; Morozov et al., 1997; Dasgupta et al., 2001; Tamai etal., 2003). On the base of these exchangeable and 
complementary characters of viral MPs, many virus-encoded proteins have been identified. Over the past 10 years, several uncharacterized proteins of rice viruses have been revealed to function in cell-to-cell movement (Table 1; Li et al., 2004; Huang et al., 2005; Xiong et al., 2008; Wu et al., 2010; Hiraguri et al., 2011, 2012; Zhang et al., 2012). In this review article, we summarized recent progress in research on cell-to-cell movement of rice viruses.

\section{RICE-INFECTING REOVIRUSES}

Five reoviruses, RDV and rice gall dwarf virus (RGDV) in the genus Phytoreovirus, rice ragged stunt virus (RRSV) in the genus Oryzavirus, and RBSDV and southern rice black-streaked dwarf virus (SRBSDV) in the genus Fijivirus, infect rice and threaten the stability of rice production in Asia (Hibino, 1996; Hoang et al., 2011). These viruses are double-shelled spherical particles, from 50 to $80 \mathrm{~nm}$ in diameter, and include from 10 to 12 segmented double-stranded genomic RNAs depending on the viruses (Attoui etal., 2011; Figure 1A). These viruses are transmitted in a persistent manner by the insects such as Laodelphax striatellus, Nilaparvata lugens, Nephotettix cincticeps, Recilia dorsalis, and Sogatella furcifera, and may be replicated in both plants and in their vector insects (Hibino, 1996). RDV can be distributed in vascular bundles and in parenchymatous cells of the host plants, but the other four are localized in the phloem and the lesioned tissues of the plants. RDV is transmitted transovarially to progeny at high rates by the vector insects, but the other four are not (Hibino, 1996; Hoang et al., 2011).

To identify the MP of rice-infecting reoviruses, Li et al. (2004) used trans-complementation experiments in leaves of Nicotiana benthamiana to analyze 12 proteins encoded in the segmented RDV genome for their ability to traffic movementdefective potato virus $\mathrm{X}$ (PVX) mutants that were tagged with $\beta$-glucuronidase (GUS) or green fluorescent protein (GFP). The cell-to-cell movement of the mutants was restored after cobombardment with only the plasmid containing the RDV gene for the non-structural Pns6, but not for any other RDV-encoded

Table 1 | Overview of movement proteins of rice viruses.

\begin{tabular}{|c|c|c|c|c|}
\hline Family/genus & Virus/abbreviation & Protein/location & Notes & Reference \\
\hline Reoviridae/Phytoreovirus & Rice dwarf virus/RDV & Pns6/Segment 6 & $\begin{array}{l}\text { Confirmed by } \\
\text { complementation }\end{array}$ & Li etal. (2004) \\
\hline Reoviridae/Phytoreovirus & Rice gall dwarf virus/RGDV & Pns7/Segment 7 & $\begin{array}{l}\text { Predicted by similarity to } \\
\text { RDV MP }\end{array}$ & $\begin{array}{l}\text { Moriyasu etal. } \\
\text { (2007) }\end{array}$ \\
\hline Reoviridae/Fijivirus & Rice black-streaked dwarf virus/RBSDV & P7-1/Segment 7 & $\begin{array}{l}\text { Predicted by tubular } \\
\text { structures }\end{array}$ & Isogai etal. (1998) \\
\hline Reoviridae/Fijivirus & $\begin{array}{l}\text { Southern rice black-streaked dwarf virus/ } \\
\text { SRBSDV }\end{array}$ & P7-1/Segment 7 & $\begin{array}{l}\text { Predicted by tubular } \\
\text { structures }\end{array}$ & Zhou etal. (2008) \\
\hline Reoviridae/Oryzavirus & Rice ragged stunt virus/RRSV & Pns6/Segment 6 & $\begin{array}{l}\text { Confirmed by } \\
\text { complementation }\end{array}$ & Wu et al. (2010) \\
\hline Unassigned family/Tenuivirus & Rice stripe virus/RSV & pC4/RNA 4 & $\begin{array}{l}\text { Confirmed by } \\
\text { complementation }\end{array}$ & Xiong et al. (2008) \\
\hline Unassigned family/Tenuivirus & Rice grassy stunt virus/RGSV & pC6/RNA 6 & $\begin{array}{l}\text { Confirmed by } \\
\text { complementation }\end{array}$ & $\begin{array}{l}\text { Hiraguri et al. } \\
\text { (2011) }\end{array}$ \\
\hline Unassigned family/Tenuivirus & Rice hoja blanca virus/RHBV & pC4/RNA 4 & $\begin{array}{l}\text { Predicted by similarity to } \\
\text { RSV MP }\end{array}$ & Zhang et al. (2012) \\
\hline Rhabdoviridae/Nucleorhabdovirus & Rice transitory yellowing virus/RTYV & P3/gene 3 & $\begin{array}{l}\text { Confirmed by } \\
\text { complementation }\end{array}$ & Huang et al. (2005) \\
\hline Unassigned family/Sobemovirus & Rice yellow mottle virus/RYMV & P1/ORF 1 gene & $\begin{array}{l}\text { Confirmed by } \\
\text { mutagenesis }\end{array}$ & $\begin{array}{l}\text { Bonneau et al. } \\
\text { (1998) }\end{array}$ \\
\hline Caulimoviridae/Tungrovirus & Rice tungro bacilliform virus/RTBV & Unknown/ORF 3 gene & $\begin{array}{l}\text { Predicted by similarity to } \\
\text { caulimoviral MP }\end{array}$ & $\begin{array}{l}\text { Bouhida et al. } \\
\text { (1993) }\end{array}$ \\
\hline Secoviridae/Waikavirus & Rice tungro spherical virus/RTSV & Unknown/ORF 2 gene & $\begin{array}{l}\text { Predicted by genome } \\
\text { organization }\end{array}$ & $\begin{array}{l}\text { Sanfacon et al. } \\
\text { (2011) }\end{array}$ \\
\hline Unassigned family/Benyvirus & Rice stripe necrosis virus/RSNV & TGB/RNA2 & $\begin{array}{l}\text { Predicted by triple gene } \\
\text { blocks-like structure }\end{array}$ & $\begin{array}{l}\text { Lozano and } \\
\text { Morales (2009) }\end{array}$ \\
\hline Potyviridae/Bymovirus & Rice necrosis mosaic virus/RNMV & P1/RNA2 & $\begin{array}{l}\text { Predicted by similarity to } \\
\text { bymoviral MP }\end{array}$ & Badge etal. (1997) \\
\hline
\end{tabular}



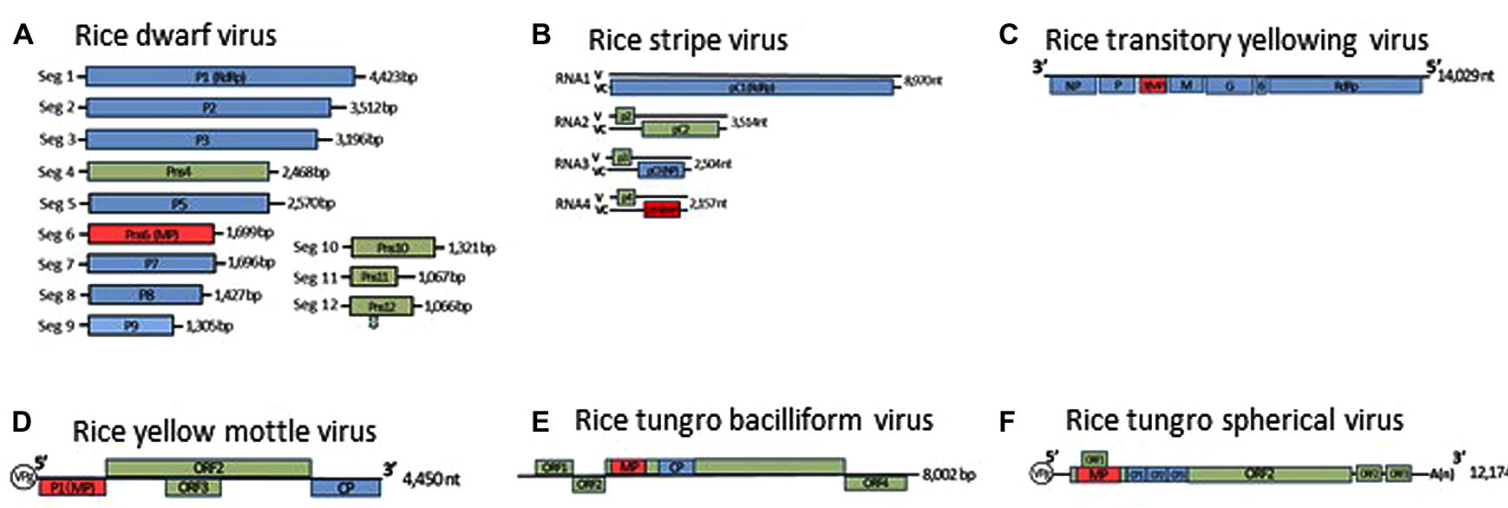

F Rice tungro spherical virus

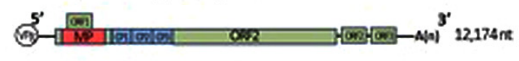

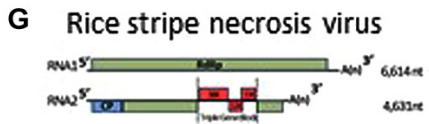

FIGURE 1 | Genome organization of rice dwarf virus (A), rice stripe virus (B), rice transitory yellowing virus (C), rice yellow mottle virus (D), rice tungro bacilliform virus $(E)$, rice tungro spherical virus $(F)$, and rice stripe necrosis virus (G). Lines represent the viral genomic segments. Blue boxes

proteins. The complementation of viral movement was lost when the translation start codon of the gene for the Pns6 was altered from ATG to ATC. Furthermore, the GFP-fused Pns6 protein was localized near or within cell walls of epidermal cells of Nicotiana tabacum. Immunogold-labeling studies of thin sections from RDV-infected rice leaves using a Pns6-specific antibody showed that the Pns6 accumulated in PD of RDV-infected rice leaf cells. These results suggested that the Pns6 of RDV is the viral MP (Li et al., 2004).

Numerous studies about MPs encoded by diverse plant viruses have indicated that viral MPs have a sequence-nonspecific nucleic-acid binding activity, which might represent a functional hallmark of viral MPs (Waigmann et al., 2004). The Pns6 of RDV has such sequence-non-specific binding of single- and double-stranded forms of DNAs and RNAs, but bind sequence-specifically to single-stranded forms of the viral genome, in particular, to the terminal consensus sequences of the segmented viral genome. Interestingly, the Pns6 had a stronger binding affinity to the terminal viral-sense strands than to the corresponding viral-complementary-sense strands of the RDV genome. There is a possibility that the differential binding affinity of the Pns6 may be associated with the formation of vRNPs when RDV moves through PD. In a mutagenesis analysis of Pns6, the N-terminal region of the protein was found to be responsible for the RNA-binding activities, and the conserved GKS motif, which is required for NTP binding, was also present at amino acid positions 125-127 (Ji etal., 2011). In the C-terminal region of the Pns6, the ATPase/helicase activity site, which may be involved in the unfolding of vRNPs during viral movement, was located (Lucas, 2006; Ji et al., 2011). denote genes for structural proteins, green are for non-structural proteins, red are for movement proteins (MP). CP, Coat protein; NP, nucleocapsid protein; ORF, open reading frame; RdRp, RNA-dependent RNA polymerase; $V$, viral-sense strand; VC, viral-complementary-sense strand.
Pns7 of RGDV, which belongs to the same genus as RDV, is very similar to Pns6 of RDV in its amino acid sequence (Moriyasu et al., 2007). Thus, Pns7 of RGDV is assumed be functionally equivalent to Pns6 of RDV in viral movement. However, there is no direct experimental evidence to support the function of the Pns7 of RGDV as a MP.

The functioning of the non-structural Pns6 protein of RRSV in viral cell-to-cell movement has been confirmed by transientexpression experiments with the GFP-fused Pns6 protein of RRSV in epidermal cells of Nicotiana benthamiana and by trans-complementation experiments using a movement-defective TMV mutant in Nicotiana tabacum (Shao et al., 2004; Wu et al., 2010). Pns6 has a sequence-non-specific binding of single- and double-stranded forms of DNAs and RNAs, but binds sequencespecifically to single-stranded forms of the viral genome, and its binding domain was also determined to be located between amino acids 201 and 273 of the Pns6 of RRSV (Shao etal., 2004).

The formation of tubules that contain virus particles has been reported for many spherical viruses and considered to facilitate intercellular movement of the virus particles through the tubule structures (van Lent et al., 1991; Storms et al., 1995; Kasteel et al., 1996, 1997; Zheng etal., 1997). Similar tubular structures containing virus particles were observed in the cytoplasm of RBSDV-infected rice plants and in viruliferous vector insects (Isogai et al., 1998). Immunogold-labeled thin sections of these virus-infected rice plants and viruliferous insects indicated that the P7-1, encoded in the $5^{\prime}$-terminal region of RBSDV segment 7 , was associated with virus-containing tubular structures (Isogai et al., 1998). Since deletion of either of two putative transmembrane domains abolishes the localization of P7-1 in the PD of 
Nicotiana benthamiana and the formation of the tubular structure in the Sf9 insect cells, these putative transmembrane domains are necessary for the P7-1 proteins to form the tubular structures (Sun et al., 2013). Thus, P7-1 is considered to function as a tubuleforming MP in both the plants and the insects, and the virus may be transported within the virus-containing tubular structures in the form of virus particles. P7-1 of SRBSDV has also been reported to function similarly in tubular formation (Zhou et al., 2008; Liu et al., 2011). However, there is no direct experimental evidence that these two proteins facilitate the cell-to-cell movement of movement-defective viruses by co-expression of these putative MPs.

\section{RICE-INFECTING TENUIVIRUSES}

Tenuiviruses are non-enveloped, segmented, negative-sense RNA viruses. The genus presently comprises six species and six tentative species (Shirako et al., 2011). Virus particles are thin and filamentous, 3-10 $\mathrm{nm}$ in diameter, and composed of a single nucleocapsid protein. The viral genomes consist of four to six single-stranded RNA segments, which are either of negative polarity or of ambisense (Figure 1B). Since the putative RNA-dependent RNA polymerase is co-purified with viral ribonucleoproteins, the polymerase is thought to be associated with filamentous virus particles (Toriyama, 1986). Three tenuiviruses, RSV, RGSV, and rice hoja blanca virus (RHBV), were reported to cause serious problems for rice production in the world (Hibino, 1996). These viruses are transmitted in a persistent manner by the insects, such as L. striatellus, Nilaparvata lugens, and Sogatodes orizicola, and multiply in these insects as well as the plants. RSV and RHBV are transmitted transovarially to progeny at high rates by the vector insects, but RGSV is not (Hibino, 1996).

The RSV and RHBV genomes consist of four single-stranded RNA segments, designated RNAs 1-4 in order of decreasing molecular mass, and encode seven genes. The first RNA segment is of negative polarity, and the other three RNA segments are ambisense. The RGSV genome consists of six single-stranded RNA segments, all of which are ambisense, and includes 12 genes. The viral mRNAs are transcribed from each viral segment by the cap-snatching mechanism (Ramirez et al., 1995; Shimizu etal., 1996).

The pC4 is encoded by the viral-complementary-sense strand of RSV RNA4. Previous computer analysis of the secondary protein structures has predicted that the $\mathrm{pC} 4$ belongs to the "30K" superfamily of viral MPs (Melcher, 2000). As a result of co-expression of the GFP-fused pC4 protein with a PD marker protein, PDLP1a, both proteins localized together as punctate spots in cell walls (Yuan et al., 2011). An immunogold-labeling study of thin sections from the RSV-infected rice leaves using a pC4-specific antibody showed that the pC4 accumulated in cell walls of the RSV-infected rice leaves, confirming that the pC4 is a PD-localized protein (Xiong et al., 2008).

Similar to other viral MPs with sequence-non-specific binding to nucleic acids (Waigmann etal., 2004), pC4 showed sequence-non-specific single- and double-stranded RNAbinding properties in gel mobility shift assays (Xiong etal., 2008). Trans-complementation experiments using a GUS-tagged, movement-defective PVX mutant and later using GFP-tagged movement-defective mutants of tomato mosaic virus (ToMV) or TMV in Nicotiana benthamiana demonstrated repeatedly that pC4 complemented cell-to-cell movement of these movementdefective mutants, reinforcing the idea that $\mathrm{pC} 4$ functions as the viral MP (Xiong etal., 2008; Hiraguri etal., 2011; Zhang et al., 2012).

It is likely that RSV may be transported between plant cells in the movement form of a vRNP, rather than as a virus particle because yeast two-hybrid assays failed to show any interaction between the pC4 and the nucleocapsid protein of RSV (Xiong et al., 2008). Interestingly, inoculation of Nicotiana benthamiana with RNA transcripts of a TMV-pC4 hybrid, in which the pC4 gene was inserted under the CP subgenomic RNA promoter of the movement-defective TMV mutant, induced foliar necrosis in the upper leaves (Zhang et al., 2012). These results indicated that the pC4 supported not only the cell-to-cell movement but also long-distance movement of the TMV mutant. Similar results that showed the " $30 \mathrm{~K}$ " superfamily members of viral MPs support longdistance movement have been reported for several phylogenetically distinct viruses such as TMV (Knapp et al., 2001) and tomato spotted wilt virus (TSWV; Lewandowski and Adkins, 2005).

The $\mathrm{pC} 4$ protein of RSV requires an actomyosin motility system to access the PD via intracellular movement along the ER-toGolgi secretory pathway (Yuan et al., 2011). Dominant-negative inhibitors were used to show that myosin VIII of the host plant cells was specifically required for pC4 localization to the PD. Myosin VIII was similarly shown to be associated with the localization of the viral MP to the PD in studies of a closteroviral MP, an Hsp70 homolog of beet yellows virus (BYV), although the same class of myosin was ineffective with respect to targeting the TMV MP, which required a myosin XI-2 to facilitate intracellular movement of TMV (Alzhanova et al., 2001; Avisar et al., 2008; Harries et al., 2009).

Although the pC4 of RSV accesses PD along the ER-to-Golgi secretory pathway, it does not have typical structural features of secreted proteins. Since pC4 lacks an N-terminal signal peptide, a transmembrane domain, and a short C-terminal tail that might direct the viral MP to the $\mathrm{PD}$, intracellular movement of $\mathrm{pC} 4$ might involve the interaction of pC4 with host cellular proteins that are transported by Golgi-derived vesicles and are eventually anchored to the PD. With a yeast two-hybrid system using pC4, two chaperone proteins, which have high degrees of identity with a DnaJ, and a Hsp20 have been isolated from a rice cDNA library ( $\mathrm{Lu}$ et al., 2009). Continuing research on the movement of TMV, BYV, TSWV, and potato virus Y (Soellick et al., 2000; Prokhnevsky et al., 2002; Qiu et al., 2006; Hofius et al., 2007; Shimizu et al., 2009) has shown that DnaJ proteins bind to their partner heat shock proteins of the host plant cells and seem to act as a key regulator for conformational change in the movement form of the vRNPs that allows them to pass through the PD. The heat shock proteins might have intrinsic ATPase activity and serve as motor proteins to facilitate the transport of the vRNPs through the PD. However, the actual roles of the two proteins from the rice cDNA library are unknown. The molecular mechanism by which the pC4 of RSV targets and modifies the PD for viral movement needs to be clarified. 
Aside from pC4 of RSV, only the pC6 protein encoded by the viral-complementary-sense strand of RGSV RNA6, has been proven to function as a viral MP (Hiraguri et al., 2011) as shown by transient expression assays with a GFP-fused pC6 protein and a trans-complementation experiment with a movement-defective ToMV mutant. The functional similarities between the RSV pC4 and the RGSV pC6 are consistent with a previous prediction that RGSV RNA 6 may be functionally equivalent to RSV RNA 4 (Toriyama et al., 1997). The MP of RHBV has not yet been identified. However, the pC4 of PHBV shared a considerably high degree of similarity with the pC4 of RSV as well as the pC6 of RGSV, suggesting a common role for the pC4 orthologs in movement of tenuiviruses (Zhang et al., 2012).

\section{RICE-INFECTING RHABDOVIRUSES}

Rice transitory yellowing virus was first identified in Taiwan in 1965 (Chiu et al., 1965) and is identical to rice yellow stunt virus (RYSV; Hiraguri et al., 2010), which was reported at almost the same time in China (Fan etal., 1965). RTYV is a member of the genus Nucleorhabdovirus in the family Rhabdoviridae and has bullet-shaped particles 180-210 nm long and $94 \mathrm{~nm}$ wide and has a non-segmented, negative-sense, single-stranded RNA genome (Figure 1C; Dietzgen et al., 2011). The virus is transmitted in a persistent manner by the insects Nephotettix nigropictus, Nephotettix cincticeps, and Nephotettix virescens (Chiu et al., 1965). On the basis of an SDS-PAGE analysis of the purified virus, the virus particles were first thought to consist of five proteins: nucleocapsid protein, phosphoprotein, matrix protein, glycoprotein, and RNAdependent RNA polymerase (Hayashi and Minobe, 1985; Chiu et al., 1990; Fang et al., 1992). In recent western blot analyses and immunogold-labeling studies of the purified virus, however, the P3 and the P6 encoded by the RTYV genes 3 and 6, respectively, has also been detected in the purified virus (Huang et al., 2003; Hiraguri et al., 2012).

The genome organizations of plant-infecting rhabdoviruses are unique in having genes in addition to the basic gene orders of rhabdoviruses (Dietzgen et al., 2011). Because the gene 3, located between the genes $\mathrm{P}$ and $\mathrm{M}$, has been identified in the genomes of all plant-infecting rhabdoviruses but not in animal-infecting rhabdoviruses (Scholthof et al., 1994; Wetzel et al., 1994; Tsai et al., 2005), the proteins encoded by gene 3 were inferred to be MPs of plant-infecting rhabdoviruses. A possible MP role for the protein encoded by gene 3 was first proposed for the sc4 protein of sonchus yellow net virus (SYNV; Scholthof et al., 1994). When the predicted secondary structure of sc4 was compared with that of known viral MPs, the sc 4 was categorized in the " $30 \mathrm{~K}$ " superfamily of viral MPs (Melcher, 2000). Other proteins encoded by the gene 3 of plantinfecting rhabdoviruses, such as P3 of RYSV, $4 \mathrm{~b}$ of lettuce necrotic yellows virus (LNYV), P3 of maize mosaic virus (MMV), and P4 of maize fine streak virus (MFSV), were also predicted to form " $30 \mathrm{~K}$ " superfamily-like secondary structures and had conserved consensus motifs homologous to the LXDX50-70G motif in the "30K" superfamily members (Huang et al., 2005).

Knowledge about the MP of plant-infecting rhabdoviruses has further advanced through the studies of the P3 protein of RTYV (synonym of RYSV). The trans-expressed of P3 facilitated cell-tocell movement of a movement-defective PVX mutant in Nicotiana benthamiana leaves (Huang et al., 2005), and also complemented a defect in movement of a movement-defective ToMV mutant (Hiraguri et al., 2012). In transient-expression experiments with the GFP-fused P3 protein of RTYV in epidermal cells of Nicotiana benthamiana, P3 was associated with the nucleus and the PD. Furthermore, in immunogold-labeled thin sections of the RTYV-infected rice plants, P3 was located in the cell walls. In addition, a northwestern blot of P3 indicated that it had a singlestranded RNA-binding capacity that lacks sequence specificity in vitro (Huang et al., 2005). Together, these data directly suggested that $\mathrm{P} 3$ is a rhabdovirus MP.

An interaction between P3 and the nucleocapsid protein was also revealed in a GST pull-down assay with E. coli-expressed recombinant proteins of RTYV (Huang etal., 2005). On the other hand, sc4 of SYNV interacts specifically with the glycoprotein and not with the nucleocapsid protein in bimolecular fluorescence complementation experiments that examined all pairwise interactions of SYNV-encoded proteins (Min et al., 2010). In addition, the $Y$ of potato yellow dwarf virus (PYDV), which is the MP of PYDV, interacted with the matrix protein, but not the nucleocapsid protein (Bandyopadhyay et al., 2010). Since the ribonucleocapsid is the minimal infectious unit for negative-strand viruses such as the rhabdoviruses, the sc4 and Y proteins may bind directly to the glycoprotein and matrix protein, respectively, and may associate indirectly with the nucleocapsid protein to form the viral movement complex with the nucleocapsid. In contrast, P3 of RTYV may interact directly with the nucleocapsid protein and be associated with the ribonucleocapsid core of virus particles (Hiraguri et al., 2012). The presence of P3 in the virus particles may provide an advantage for rapid viral spread to neighboring cells from the initially infected cells where the enveloped virus particles are uncoated, with subsequent release of the nucleocapsid cores. In the initial infection process of rhabdoviruses, numerous virus particles are thought to be injected into plant cells via their insect vector. Translation or replication of some virus particles may begin in the initially injected cells. Others may form an intercellular movement complex of the ribonucleocapsid immediately after they enter the neighbor cells, with the assistance of the MP that had been contained in the virus particles beforehand, and could be transported more rapidly into neighboring cells. The cell-to-cell movement strategy of the RTYV-type rhabdoviruses might be distinct from those of other enveloped plant viruses.

\section{OTHER RICE-INFECTING VIRUSES RICE YELLOW MOTTLE VIRUS}

Rice yellow mottle virus is a member of the genus Sobemovirus (Truve and Fargette, 2011). The virus is endemic to Africa and causes serious problems for irrigated rice. The virus is polyhedral, $30 \mathrm{~nm}$ in diameter, and is transmitted in a semipersistent manner by a number of chrysomelid beetles including Sesselia pussilla, Chaetocnema pulla, and Trichispa sericea (Hibino, 1996). The RYMV genome is composed of a positive-sense, single-stranded RNA and contains four open reading frames (ORFs; Figure 1D; Yassi et al., 1994; Truve and Fargette, 2011). An RYMV mutant that lacks expression of the P1 protein as a result of a point 
mutation in the ORF1 initiation codon of RYMV ORF1, replicates efficiently in rice protoplasts, but is unable to systemically infect rice plants. In transgenic plants that express $\mathrm{P} 1$ in trans, the defective mutant virus recovered its ability for systemic infection (Bonneau et al., 1998). These results indicated that P1 is the RYMV MP. P1 also has silencing suppressor activity, and mutagenesis experiments using the RYMV infectious clone revealed that cysteine at amino acid position 95 of $\mathrm{P} 1$ is essential for viral cell-to-cell movement and that cysteine and phenylalanine at amino acids 64 and 88 are associated with the efficiency of the RNA silencing suppressor (Voinnet et al., 1999; Sire et al., 2008).

\section{TUNGRO DISEASE-ASSOCIATED VIRUSES}

Tungro disease, one of the most severe virus diseases of rice, is a significant threat to rice production in South and Southeast Asia (Hibino, 1996). Tungro disease is caused by a complex of two viruses, RTBV and RTSV. RTBV is mainly responsible for symptom expression, and RTSV assists transmission of both viruses by the insects Nephotettix virescens, Nephotettix nigropictus, Nephotettix cincticeps, and Recilia dorsalis (Hibino et al., 1978; Jones et al., 1991).

Rice tungro bacilliform virus is a member of the genus Tungrovirus in the family Caulimoviridae (Geering and Hull, 2011). The virus particles are bacilliform, 100-300 nm long and 30$35 \mathrm{~nm}$ wide, and its genome is circular, double-stranded DNA and contains four ORFs (Figure 1E). ORF3 encodes the largest polyprotein, which possesses the coat protein and the analogs of a pepsin-like aspartic protease, reverse transcriptase, and RNase H1 (Rothnie et al., 1994).

The identity of the participants and understanding of the mechanism for cell-to-cell movement of caulimoviruses has progressed through studies of the P1 protein of cauliflower mosaic virus (CaMV). P1 forms tubular structures that contains the virus particles. A mutation in the CaMV gene for the P1 abolishes viral movement but does not affect viral amplification. For these reasons, $\mathrm{P} 1$ of $\mathrm{CaMV}$ has been proposed as a viral MP (Perbal etal., 1993; Thomas etal., 1993). The Nterminal 350 amino acids of the protein encoded by the RTBV ORF3 contains a region with restricted similarity to the P1 protein of CaMV (Bouhida etal., 1993). Based on this similarity with $\mathrm{P} 1$, the N-terminal region of the protein has also been postulated to be a MP of RTBV, but there is no direct experimental evidence that the region is associated with movement of RTBV.

Rice tungro spherical virus is the type member of the genus Waikavirus in the family Secoviridae, characterized by positivesense, single-stranded RNA. Virus particles are polyhedral, about $30 \mathrm{~nm}$ in diameter and consist of three CPs (CP1, CP2, and CP3; Sanfacon et al., 2011). The viral genome is presumably attached to the genome-linked viral protein $(\mathrm{VPg})$ at the $5^{\prime}$-terminal and is polyadenylated at the $3^{\prime}$-terminus (Figure 1F). The viral genome encodes one large ORF encoding a viral polyprotein, which contains the regions of the three CPs, the cysteine-like protease, domains for an NTP-binding protein and an RNA-dependent RNA polymerase (Shen et al., 1993). In addition, two small ORFs near the $3^{\prime}$-terminal of the viral genome and one small ORF that overlaps the gene for the main viral polyprotein have been identified (Shen et al., 1993; Firth and Atkins, 2008). The gene for the MP of RTSV has not been identified yet, and there is no information on the molecular mechanism for cell-to-cell movement of waikaviruses. However, the several genes for viral MPs in the family Secoviridae have been identified, and a comparison of the genome organization of the waikaviruses with other members of the family Secoviridae led to the suggestion that the region for the MP of RTSV might be located at the Nterminal region of the large viral polyprotein and be followed by three CPs (Sanfacon et al., 2011). Further experiments such as trans-complementation experiments using different movementdefective virus mutants or subcellular localization experiments using these putative MPs fused with fluorescent protein, are needed to investigate the molecular mechanisms of movement of RTSV.

\section{FUNGUS-TRANSMITTED RICE VIRUSES}

Two rice viruses, RSNV and RNMV, were reported to be transmitted by a soil-inhabiting fungus, Polymyxa graminis (Hibino, 1996). RSNV is a tentative species of the genus Benyvirus (Gilmer and Ratti, 2011). The virus continues to spread in Latin America through the international trades of rice seeds produced in fields contaminated with virus-carrying fungal vectors. The virus particles have at least two rod-shaped structures that are 360 and $260 \mathrm{~nm}$ long, respectively, and $20 \mathrm{~nm}$ wide (Morales et al., 1999). The RSNV genome consists of two single-stranded RNAs, and its genome organization is nearly identical to those of beet necrotic yellow vein virus (BNYVV; Figure 1G; Lozano and Morales, 2009). RNA 2 of RSNV possesses three overlapping ORFs that code for polypeptides of $38.4,12.3$, and $15 \mathrm{kDa}$ at amino acid positions 2194-3975, which have a typical motif of triple gene blocks (TGB). The amino acid sequences of these three overlapping ORFs of RSNV are closely related to the TGB of BNYVV, which has been revealed by site-directed mutagenesis as essential for viral movement (Gilmer et al., 1992). These polypeptides are hypothesized to be involved in movement of the virus in infected plants, but again there is no direct experimental evidence to support this hypothesis.

Rice necrosis mosaic virus is a species of the genus Bymovirus in the family Potyviridae (Adams et al., 2011). The virus particles have flexuous, filamentous structures 550 and $205 \mathrm{~nm}$ long and 13-14 nm wide and contain two single-stranded RNAs (Inouye and Fujii, 1977). The virus has been found in Japan and India, but is now less troublesome in these countries. RNMV is serologically related to barley yellow mosaic virus, and only the partial nucleotide sequence at the $3^{\prime}$-terminal of the RNMV RNA1 has so far been determined (Badge etal., 1997). By a reserve genetic system for BaYMV, the P1 protein that is encoded at the $5^{\prime}$-terminal of the BaYMV RNA2 has been indicated to be involved in viral movement (You and Shirako, 2010). Similarly then, the corresponding P1 encoded at the $5^{\prime}$-terminal of the RNMV RNA2 might also be involved in movement of RNMV. Further analyses are, however, required to determine the complete genome structure of RNMV and investigate the molecular mechanisms of its cell-to-cell movement. 


\section{CONCLUSION AND PERSPECTIVES}

Viral MPs are defined experimentally; when the proteins are mutagenized, they interfere with viral cell-to-cell movement but do not affect virus replication competence in single cells. By using reverse genetic systems for plant viruses, many virusencoded proteins have been confirmed as viral MPs. But the complexity of the unusual genome organizations and replication strategies for many rice viruses have so far prevented the development of infectious clone systems. To date, only two infectious clone systems of RTBV and RYMV have been developed (Dasgupta etal., 1991; Bonneau etal., 1998). Lack of reverse genetic systems for the rice viruses has made it impossible to use standard mutagenesis methods for functional studies of their encoded proteins that are involved in viral cell-to-cell movement. The viral MP of one particular virus can, however, complement movement not only of closely related but also of distantly related or even unrelated viruses, in spite of the striking diversity of viral movement strategies and the lack of amino acid sequence similarities among the MPs of different virus groups (Nejidat et al., 1991; Solovyev et al., 1996; Morozov et al., 1997; Morozov and Solovyev, 2003; Tamai et al., 2003). By a different experimental approach, that is, using movement-defective viruses by trans-complementation experiments with virus proteins of interest, the movement functions of several uncharacterized proteins of rice viruses have been determined (Table 1; Li et al., 2004; Huang et al., 2005; Xiong et al., 2008; Wu etal., 2010; Hiraguri et al., 2011, 2012; Zhang et al., 2012).

One of the unique features that many rice viruses are amplified in both plant and insect cells. The Pns10 protein of RDV forms tubular structures in cells of the insect vector and is thought to be associated with intercellular movement in the insect (Wei et al., 2006, 2008; Chen etal., 2012), but the protein does not facilitate movement of the movement-defective PVX mutant in plants (Li et al., 2004). The Pns6 protein of RDV functions as a viral MP in plants, but similar tubular structures are rarely found in RDV-infected rice plants (Fukushi et al., 1962; Shikata, 1969; Boccardo and Milne, 1984). These results indicated that the strategy for intercellular movement by RDV in the insect seems to differ from that in the plant. In contrast, P7-1 of RBSDV forms tubular structures containing virus particles in the RBSDVinfected rice plants and the viruliferous insects, and the protein is considered to function as the tubule-forming MP in both the host plants and the insects (Isogai et al., 1998). The differences in the strategy for movement in plants between RDV and RBSDV may be associated with their different distributions in the plants; RDV is distributed in vascular bundles and in parenchymatous cells, and RBSDV is localized only in the plant phloem and tissues with lesions. Or these unique features of the viral MPs of rice viruses may be required specifically to infect monocotyledonous rice plants. But there is little information on the molecular details for the cell-to-cell movements of rice viruses because most of well-known MPs are encoded in the viruses that infect dicotyledonous plants. To advance research on cellto-cell movements of rice viruses, efficient experimental methods, such as complementary systems, that work in monocotyledonous plants must be developed; most experimental methods have been developed for dicotyledonous plants and their viruses rather than for monocotyledonous plants.

Plant viruses recruit host factors that facilitate viral cell-tocell movement through PD and influence the efficiency of viral movement. Numerous studies on the interactions between viral MPs and host factor(s) have progressively revealed the molecular mechanisms by which viral MPs target and modify PD for viral movement (Chen and Citovsky, 2003; Min et al., 2010; Ueki et al., 2010; Amari et al., 2011). Many host factors involved in viral movement have been identified from dicotyledonous plants, but not as many host factors have been identified for monocotyledonous plants (Lu et al., 2009). To advance research on cell-to-cell movement of the rice viruses, we also need to learn more about the host factors that interact with viral MPs during the PD gating process. More experimental evidence is critically needed to understand the molecular details for the cell-to-cell movement of rice viruses and to elucidate the mechanisms underlying movement strategies of viruses in rice.

\section{ACKNOWLEDGMENTS}

The authors are grateful to Dr. T. Omura for greatly advancing rice virus research. This work was supported by a grant from the Program for Promotion of Basic Research Activities for Innovative Biosciences of the Bio-Oriented Technology Research Advancement Institution (BRAIN) and by a grant from the Ministry of Agriculture, Forestry, and Fisheries of Japan (Genomic for Agricultural Innovation, GMA-0003).

\section{REFERENCES}

Adams, M. J., Zerbini, F. M., French, R., Rabenstein, F., Stenger, D. C., and Valkonen, J. P. T. (2011). "Family Potyviridae," in Virus Taxonomy: Classification and Nomenclature. Ninth Report of the International Committee on Taxonomy of Viruses, eds A. M. Q. King, M. J. Adams, E. B. Carstens, and E. J. Lefkowitz (San Diego, CA: Academic Press), 1069-1089.

Alzhanova, D. V., Napuli, A. J., Creamer, R., and Dolja, V. V. (2001). Cell-to-cell movement and assembly of a plant closterovirus: roles for the capsid proteins and Hsp70 homolog. EMBO J. 20, 6997-7007. doi: 10.1093/emboj/20.24.6997

Amari, K., Lerich, A., Schmitt-Keichinger, C., Dolja, V. V., and Ritzenthaler, C. (2011). Tubule-guided cell-to-cell movement of a plant virus requires class XI myosin motors. PLoS Pathog. 7:e1002327. doi: 10.1371/journal.ppat. 1002327

Atabekov, J. G., and Dorokhov, Y. L. (1984). Plant virus-specific transport function and resistance of plants to viruses. Adv. Virus Res. 29, 313-364. doi: 10.1016/S0065-3527(08)60412-1

Attoui, H., Mertens, P. P. C., Becnel, J., Belaganahalli, S., Bergoin, M., Brussaard, C. P., et al. (2011). "Family Reoviridae," in Virus Taxonomy: Classification and Nomenclature. Ninth Report of the International Committee on Taxonomy of Viruses, eds A. M. Q. King, M. J. Adams, E. B. Carstens, and E. J. Lefkowitz (San Diego, CA: Academic Press), 541-637.

Avisar, D., Prokhnevsky, A. I., and Dolja, V. V. (2008). Class VIII myosins are required for plasmodesmatal localization of a closterovirus Hsp70 homolog. J. Virol. 82, 2836-2843. doi: 10.1128/JVI.02246-07

Badge, J. L., Kashiwazaki, S., Lock, S., and Foster, G. D. (1997). A bymovirus PCR primer and partial nucleotide sequence provides further evidence for the recognition of rice necrosis mosaic virus as a bymovirus. Eur. J. Plant Pathol. 103, 721-724. doi: 10.1023/A:1008617423616

Bandyopadhyay, A., Kopperud, K., Anderson, G., Martin, K., and Goodin, M. (2010). An integrated protein localization and interaction map for potato yellow dwarf virus, type species of the genus Nucleorhabdovirus. Virology 402, 61-71. doi: 10.1016/j.virol.2010.03.013

Benitez-Alfonso, Y., Faulkner, C., Ritzenthaler, C., and Maule, A. J. (2010). Plasmodesmata: gateways to local and systemic virus infection. Mol. Plant Microbe Interact. 23, 1403-1412. doi: 10.1094/MPMI-05-10-0116 
Boccardo, G., and Milne, R. G. (1984). “Plant reovirus group,” in CMI/AAB Descriptions of Plant Viruses, no. 294, eds A. F. Morant and B. D. Harrison (Old Woking: Gresham Press), 1-7.

Bonneau, C., Brugidou, C., Chen, L., Beachy, R. N., and Fauquet, C. (1998). Expression of the rice yellow mottle virus P1 protein in vitro and in vivo and its involvement in virus spread. Virology 244, 79-86. doi: 10.1006/viro. 1998.9100

Bouhida, M., Lockhart, B. E. L., and Olszewski, N. E. (1993). An analysis of the complete sequence of a sugarcane bacilliform virus genome infectious to banana and rice. J. Gen. Virol. 74, 15-22. doi: 10.1099/0022-1317-74-1-15

Chen, M. H., and Citovsky, V. (2003). Systemic movement of a tobamovirus requires host cell pectin methylesterase. Plant J. 35, 386-392. doi: 10.1046/j.1365313X.2003.01818.x

Chen, Q., Chen, H., Mao, Q., Liu, Q., Shimizu, T., Uehara-Ichiki, T., et al. (2012). Tubular structure induced by a plant virus facilitates viral spread in its vector insect. PLoS Pathog. 8:e1003032. doi: 10.1371/journal.ppat.1003032

Chiu, R. J., Hsu, Y. H., Chen, M. J., Chen, C. C., Lee, R. C. R., Lin, M. C., et al. (1990). Purification and partial characterization of rice transitory yellowing virus. Phytopathology 80, 777-783. doi: 10.1094/Phyto-80-777

Chiu, R. J., Lo, T. C., Pi, C. T., and Chen, M. H. (1965). Transitory yellowing of rice and its transmission by the leafhopper Nephotettix apicalis (Motsch). Bot. Bull. Acad. Sin. 6, 1-18.

Dasgupta, I., Hull, R., Eastop, S., Poggi-Pollini, C., Blakebrough, M., Boulton, M. I., et al. (1991). Rice tungro bacilliform virus DNA independently infects rice after Agrobacterium-mediated transfer. J. Gen. Virol. 72, 1215-1221. doi: 10.1099/0022-1317-72-6-1215

Dasgupta, R., Garcia, B. H., and Goodman, R. M. (2001). Systemic spread of an RNA insect virus in plants expressing plant viral movement protein genes. Proc Natl. Acad. Sci. U.S.A. 98, 4910-4915. doi: 10.1073/pnas.081288198

Dietzgen, R. G., Calisher, C. H., Kurath, G., Kuzmin, I. V., Rodriguez, L. L., Stone, D. M., et al. (2011). "Family Rhabdoviridae," in Virus Taxonomy: Classification and Nomenclature. Ninth Report of the International Committee on Taxonomy of Viruses, eds A. M. Q. King, M. J. Adams, E. B. Carstens, and E. J. Lefkowitz (San Diego, CA: Academic Press), 686-713.

Fan, H., Zeng, D. S., Ye, B. J., and Lu, B. C. (1965). The preliminary investigation on rice yellow stunt disease in Guangdong. Plant Prot. 3, 143-145.

Fang, R. X., Pang, Z., Xu, B. Y., Mang, K. Q., Li, A. M., Qin, W. S., et al. (1992). Partia purification of rice yellow stunt virus and characterization of virus structural proteins and genome. Chin. J. Viol. 8, 62-68.

Firth, A., and Atkins, J. (2008). Bioinformatic analysis suggests that a conserved ORF in the waikaviruses encodes an overlapping gene. Arch. Virol. 153, 1379-1383. doi: 10.1007/s00705-008-0119-5

Fukushi, I., Shikata, E., and Kimura, I. (1962). Some morphological characters of rice dwarf virus. Virology 18, 192-205. doi: 10.1016/0042-6822(62) 90005-3

Geering, A. D. W., and Hull, R. (2011). "Family Caulimoviridae," in Virus Taxonomy: Classification and Nomenclature. Ninth Report of the International Committee on Taxonomy of Viruses, eds A. M. Q. King, M. J. Adams, E. B. Carstens, and E. J. Lefkowitz (San Diego, CA: Academic Press), 429-443.

Gilmer, D., Bouzoubaa, S., Hehn, A., Guilley, H., Richards, K., and Jonard, G. (1992). Efficient cell-to-cell movement of beet necrotic yellow vein virus requires $3^{\prime}$ proximal genes located on RNA 2. Virology 189, 40-47. doi: 10.1016/00426822(92)90679-J

Gilmer, D., and Ratti, C. (2011). "Genus Benyvirus," in Virus Taxonomy: Classification and Nomenclature. Ninth Report of the International Committee on Taxonomy of Viruses, eds A. M. Q. King, M. J. Adams, E. B. Carstens, and E. J. Lefkowitz (San Diego, CA: Academic Press), 1163-1168.

Harries, P. A., Park, J.-W., Sasaki, N., Ballard, K. D., Maule, A. J., and Nelson, R. S. (2009). Differing requirements for actin and myosin by plant viruses for sustained intercellular movement. Proc. Natl. Acad. Sci. U.S.A. 106, 17594-17599. doi: 10.1073/pnas.0909239106

Hayashi, T., and Minobe, Y. (1985). Protein composition of rice transitory yellowing virus. Microbiol. Immunol. 29, 169-172. doi: 10.1111/j.1348-0421.1985.tb00816.x

Hibino, H. (1996). Biology and epidemiology of rice viruses. Annu. Rev. Phytopathol. 34, 249-274. doi: 10.1146/annurev.phyto.34.1.249

Hibino, H., Roechan, M., and Sudarisman, S. (1978). Association of two types of virus particles with penyakit habang (tungro disease) of rice in Indonesia. Phytopathology 68, 1412-1416. doi: 10.1094/Phyto-68-1412
Hiraguri, A., Hibino, H., Hayashi, T., Netsu, O., Shimizu, T., Uehara-Ichiki, T., et al. (2012). The movement protein encoded by gene 3 of rice transitory yellowing virus is associated with virus particles. J. Gen. Virol. 93, 2290-2298. doi: 10.1099/vir.0.044420-0

Hiraguri, A., Hibino, H., Hayashi, T., Shimizu, T., Uehara-Ichiki, T., Omura, T., et al. (2010). Complete sequence analysis of rice transitory yellowing virus and its comparison to rice yellow stunt virus. Arch. Virol. 155, 243-245. doi: 10.1007/s00705-009-0557-8

Hiraguri, A., Netsu, O., Shimizu, T., Uehara-Ichiki, T., Omura, T., Sasaki, N., etal. (2011). The nonstructural protein pC6 of rice grassy stunt virus trans-complements the cell-to-cell spread of a movement-defective tomato mosaic virus. Arch. Virol. 156, 911-916. doi: 10.1007/s00705-0110939-6

Hoang, A. T., Zhang, H. M., Yang, J., Chen, J. P., Hébrard, E., Zhou, G. H., et al. (2011). Identification, characterization, and distribution of southern rice blackstreaked dwarf virus in Vietnam. Plant Dis. 95, 1063-1069. doi: 10.1094/PDIS07-10-0535

Hofius, D., Maier, A. T., Dietrich, C., Jungkunz, I., Bornke, F., Maiss, E., et al. (2007). Capsid protein-mediated recruitment of host DnaJ-like proteins is required for potato virus Y infection in tobacco plants. J. Virol. 81, 11870-11880. doi: 10.1128/JVI.01525-07

Huang, Y., Zhao, H., Luo, Z., Chen, X., and Fang, R.-X. (2003). Novel structure of the genome of rice yellow stunt virus: identification of the gene 6-encoded virion protein. J. Gen. Virol. 84, 2259-2264. doi: 10.1099/vir.0.19195-0

Huang, Y.-W., Geng, Y.-F., Ying, X.-B., Chen, X.-Y., and Fang, R.-X. (2005). Identification of a movement protein of rice yellow stunt rhabdovirus. J. Virol. 79, 2108-2114. doi: 10.1128/JVI.79.4.2108-2114.2005

Inouye, T., and Fujii, S. (1977). "Rice necrosis mosaic virus," in CMI/AAB Descriptions of Plant Viruses, no. 172, eds A. F. Morant and B. D. Harrison (Old Woking: Gresham Press), 1-3.

Isogai, M., Uyeda, I., and Lee, B. C. (1998). Detection and assignment of proteins encoded by rice black streaked dwarf fijivirus S7, S8, S9 and S10. J. Gen. Virol. 79, 1487-1494.

Ji, X., Qian, D., Wei, C., Ye, G., Zhang, Z., Wu, Z., et al. (2011). Movement protein Pns6 of rice dwarf phytoreovirus has both ATPase and RNA binding activities. PLoS ONE 6:e24986. doi: 10.1371/journal.pone.0024986

Jones, M. C., Gough, K., Dasgupta, I., Rao, B. L. S., Cliffe, J., Qu, R., et al. (1991). Rice tungro disease is caused by an RNA and a DNA virus. J. Gen. Virol. 72, 757-761. doi: 10.1099/0022-1317-72-4-757

Kasteel, D. T., Perbal, M.-C., Boyer, J.-C., Wellink, J., Goldbach, R. W., Maule, A. J., et al. (1996). The movement proteins of cowpea mosaic virus and cauliflower mosaic virus induce tubular structures in plant and insect cells. J. Gen. Virol. 77, 2857-2864. doi: 10.1099/0022-1317-77-11-2857

Kasteel, D. T., van der Wel, N. N., Jansen, K. A., Goldbach, R. W., and Van Lent, J. W. (1997). Tubule-forming capacity of the movement proteins of alfalfa mosaic virus and brome mosaic virus. J. Gen. Virol. 78, 2089-2093.

Knapp, E., Dawson, W. O., and Lewandowski, D. J. (2001). Conundrum of the lack of defective RNAs (dRNAs) associated with tobamovirus infections: dRNAs that can move are not replicated by the wild-type virus; dRNAs that are replicated by the wild-type virus do not move. J. Virol. 75, 5518-5525. doi: 10.1128/JVI.75.12.55185525.2001

Lewandowski, D. J., and Adkins, S. (2005). The tubule-forming NSm protein from tomato spotted wilt virus complements cell-to-cell and long-distance movement of tobacco mosaic virus hybrids. Virology 342, 26-37. doi: 10.1016/j.virol.2005.06.050

Li, Y., Bao, Y. M., Wei, C. H., Kang, Z. S., Zhong, Y. W., Mao, P., et al. (2004). Rice dwarf phytoreovirus segment S6-encoded nonstructural protein has a cellto-cell movement function. J. Virol. 78, 5382-5389. doi: 10.1128/JVI.78.10.53825389.2004

Liu, Y., Jia, D., Chen, H., Chen, Q., Xie, L., Wu, Z., et al. (2011). The P7-1 protein of southern rice black-streaked dwarf virus, a fijivirus, induces the formation of tubular structures in insect cells. Arch. Virol. 156, 1729-1736. doi: 10.1007/s00705-011-1041-9

Lozano, I., and Morales, F. (2009). Molecular characterisation of rice stripe necrosis virus as a new species of the genus Benyvirus. Eur. J. Plant Pathol. 124, 673-680. doi: 10.1007/s10658-009-9453-z

Lu, L., Du, Z., Qin, M., Wang, P., Lan, H., Niu, X., et al. (2009). Pc4, a putative movement protein of rice stripe virus, interacts with a type I DnaJ protein 
and a small Hsp of rice. Virus Genes 38, 320-327. doi: 10.1007/s11262-0080324-Z

Lucas, W. J. (2006). Plant viral movement proteins: agents for cell-to-cell trafficking of viral genomes. Virology 344, 169-184. doi: 10.1016/j.virol.2005. 09.026

Melcher, U. (1990). Similarities between putative transport proteins of plant-viruses. J. Gen. Virol. 71, 1009-1018. doi: 10.1099/0022-1317-71-5-1009

Melcher, U. (2000). The “30K” superfamily of viral movement proteins. J. Gen. Virol. 81, 257-266.

Meshi, T., Watanabe, Y., Saito, T., Sugimoto, A., Maeda, T., and Okada, Y. (1987). Function of the $30 \mathrm{kD}$ protein of tobacco mosaic virus: involvement in cell-to-cell movement and dispensability for replication. EMBO J. 6, 2557-2563.

Min, B. E., Martin, K., Wang, R., Tafelmeyer, P., Bridges, M., and Goodin, M. (2010). A host-factor interaction and localization map for a plant-adapted rhabdovirus implicates cytoplasm-tethered transcription activators in cell-to-cell movement. Mol. Plant Microbe Interact. 23, 1420-1432. doi: 10.1094/MPMI-0410-0097

Morales, F. J., Ward, E., Castaño, M., Arroyave, J. A., Lozano, I., and Adams, M. J. (1999). Emergence and partial characterization of rice stripe necrosis virus and its fungus vector in South America. Eur. J. Plant Pathol. 105, 643-650. doi: 10.1023/A:1008786832634

Moriyasu, Y., Maruyama-Funatsuki, W., Kikuchi, A., Ichimi, K., Zhong, B., Yan, J., et al. (2007). Molecular analysis of the genome segments S1, S4, S6, S7 and S12 of a rice gall dwarf virus isolate from Thailand; completion of the genomic sequence. Arch. Virol. 152, 1315-1322. doi: 10.1007/s00705-0070948-7

Morozov, S., Fedorkin, O. N., Juttner, G., Schiemann, J., Baulcombe, D. C., and Atabekov, J. G. (1997). Complementation of a potato virus X mutant mediated by bombardment of plant tissues with cloned viral movement protein genes. $J$. Gen. Virol. 78, 2077-2083.

Morozov, S. Y., and Solovyev, A. G. (2003). Triple gene block: modular design of a multifunctional machine for plant virus movement. J. Gen. Virol. 84, 1351-1366. doi: 10.1099/vir.0.18922-0

Nejidat, A., Cellier, F., Holt, C. A., Gafny, R., Eggenberger, A. L., and Beachy, R. N. (1991). Transfer of the movement protein gene between two tobamoviruses: influence on local lesion development. Virology 180, 318-326. doi: 10.1016/00426822(91)90036-B

Oparka, K. J., Prior, D. A. M., Cruz, S. S., Padgett, H. S., and Beachy, R. N. (1997). Gating of epidermal plasmodesmata is restricted to the leading edge of expanding infection sites of tobacco mosaic virus (TMV). Plant J. 12, 781-789. doi: 10.1046/j.1365-313X.1997.12040781.x

Perbal, M.-C., Thomas, C. L., and Maule, A. J. (1993). Cauliflower mosaic virus gene 1 product (P1) forms tubular structures which extend from the surface of infected protoplasts. Virology 195, 281-285. doi: 10.1006/viro. 1993.1375

Prokhnevsky, A. I., Peremyslov, V. V., Napuli, A. J., and Dolja, V. V. (2002). Interaction between long-distance transport factor and Hsp70-related movement protein of beet yellows virus. J. Virol. 76, 11003-11011. doi: 10.1128/JVI.76.21.1100311011.2002

Qiu, X., Shao, Y., Miao, S., and Wang, L. (2006). The diversity of the DnaJ/Hsp40 family, the crucial partners for Hsp70 chaperones. Cell. Mol. Life Sci. 63, 2560 2570. doi: 10.1007/s00018-006-6192-6

Ramirez, B. C., Garcin, D., Calvert, L. A., Kolakofsky, D., and Haenni, A.-L. (1995). Capped nonviral sequences at the $5^{\prime}$ end of the mRNAs of rice hoja blanca virus RNA4. J. Virol. 69, 1951-1954.

Rothnie, H. M., Chapdelaine, Y., and Hohn, T. (1994). Pararetroviruses and retroviruses: a comparative review of viral structure and gene expression strategies. Adv. Virus Res. 44, 1-67. doi: 10.1016/S0065-3527(08) 60327-9

Sanfacon, H., Iwanami, T., Karasev, A. V., van der Vlugt, R., Wellink, J., Wetzel, T., et al. (2011). "Family Secoviridae," in Virus Taxonomy: Classification and Nomenclature. Ninth Report of the International Committee on Taxonomy of Viruses, eds A. M. Q. King, M. J. Adams, E. B. Carstens, and E. J. Lefkowitz (San Diego, CA: Academic Press), 881-899.

Scholthof, K.-B. G., Hillman, B. I., Modrell, B., Heaton, L. A., and Jackson, A. O. (1994). Characterization and detection of sc4: a sixth gene encoded by sonchus yellow net virus. Virology 204, 279-288. doi: 10.1006/viro. 1994.1532
Shao, C.-G., Lü, H.-J., Wu, J.-H., and Gong, Z.-X. (2004). Nucleic acid binding activity of Pns6 encoded by genome segment 6 of rice ragged stunt oryzavirus. Acta Biochim. Biophys. Sin. 36, 457-466. doi: 10.1093/abbs/36.7.457

Shen, P., Kaniewska, M., Smith, C., and Beachy, R. N. (1993). Nucleotide sequence and genomic organization of rice tungro spherical virus. Virology 193, 621-630. doi: 10.1006/viro.1993.1170

Shikata, E. (1969). "Electron microscopic studies on rice viruses," in The Virus Disease of the Rice Plant, ed. IRRI (Baltimore, MD: Johns Hopkins University Press), 223-240.

Shimizu, T., Toriyama, S., Takahashi, M., Akutsu, K., and Yoneyama, K. (1996). Non-viral sequences at the $5^{\prime}$ termini of mRNAs derived from virus-sense and virus-complementary sequences of the ambisense RNA segments of rice stripe tenuivirus. J. Gen. Virol. 77, 541-546. doi: 10.1099/0022-1317-773-541

Shimizu, T., Yoshii, A., Sakurai, K., Hamada, K., Yamaji, Y., Suzuki, M., et al. (2009). Identification of a novel tobacco DnaJ-like protein that interacts with the movement protein of tobacco mosaic virus. Arch. Virol. 154, 959-967. doi: 10.1007/s00705-009-0397-6

Shirako, Y., Falk, B. W., and Haenni, A.-L. (2011). "Genus Tenuivirus," in Virus Taxonomy: Classification and Nomenclature. Ninth Report of the International Committee on Taxonomy of Viruses, eds A. M. Q. King, M. J. Adams, E. B. Carstens, and E. J. Lefkowitz (San Diego, CA: Academic Press), 771-776.

Sire, C., Bangratz-Reyser, M., Fargette, D., and Brugidou, C. (2008). Genetic diversity and silencing suppression effects of rice yellow mottle virus and the $\mathrm{P} 1$ protein. Virol. J. 5, 55. doi: 10.1186/1743-422X-5-55

Soellick, T.-R., Uhrig, J. F., Bucher, G. L., Kellmann, J.-W., and Schreier, P. H. (2000). The movement protein NSm of tomato spotted wilt tospovirus (TSWV): RNA binding, interaction with the TSWV $\mathrm{N}$ protein, and identification of interacting plant proteins. Proc. Natl. Acad. Sci. U.S.A. 97, 2373-2378. doi: 10.1073/pnas.030548397

Solovyev, A. G., Zelenina, D. A., Savenkov, E. I., Grdzelishvili, V. Z., Morozov, S Y., Lesemann, D. E., et al. (1996). Movement of a barley stripe mosaic virus chimera with a tobacco mosaic virus movement protein. Virology 217, 435-441. doi: 10.1006/viro.1996.0137

Storms, M. M. H., Kormelink, R., Peters, D., van Lent, J. W. M., and Goldbach, R. W. (1995). The nonstructural NSm protein of tomato spotted wilt virus induces tubular structures in plant and insect cells. Virology 214, 485-493. doi: 10.1006/viro.1995.0059

Sun, Z., Zhang, S., Xie, L., Zhu, Q., Tan, Z., Bian, J., et al. (2013). The secretory pathway and the actomyosin motility system are required for plasmodesmatal localization of the P7-1 of rice black-streaked dwarf virus. Arch. Virol. 158, 10551064. doi: 10.1007/s00705-012-1585-3

Taliansky, M., Torrance, L., and Kalinina, N. O. (2008). "Role of plant virus movement proteins," in Plant Virology Protocols, eds G. D. Foster, I. E. Johansen, Y. Hong, and P. D. Nagy (New York: Humana Press), 33-54. doi: 10.1007/978-1-59745-102-4_3

Tamai, A., Kubota, K., Nagano, H., Yoshii, M., Ishikawa, M., Mise, K., et al. (2003). Cucumovirus- and bromovirus-encoded movement functions potentiate cell-to-cell movement of tobamo- and potexviruses. Virology 315, 56-67. doi: 10.1016/S0042-6822(03)00480-X

Thomas, C. L., Perbal, C., and Maule, A. J. (1993). A mutation of cauliflower mosaic virus gene 1 interferes with virus movement but not virus replication. Virology 192, 415-421. doi: 10.1006/viro.1993.1056

Toriyama, S. (1986). An RNA-dependent RNA polymerase associated with the filamentous nucleoproteins of rice stripe virus. J. Gen. Virol. 67, 1247-1255. doi: 10.1099/0022-1317-67-7-1247

Toriyama, S., Kimishima, T., and Takahashi, M. (1997). The proteins encoded by rice grassy stunt virus RNA5 and RNA6 are only distantly related to the corresponding proteins of other members of the genus Tenuivirus. J. Gen. Virol. 78, 2355-2363.

Truve, E., and Fargette, D. (2011). "Genus Sobemovirus," in Virus Taxonomy: Classification and Nomenclature. Ninth Report of the International Committee on Taxonomy of Viruses, eds A. M. Q. King, M. J. Adams, E. B. Carstens, and E. J. Lefkowitz (San Diego, CA: Academic Press), 1185-1189.

Tsai, C. W., Redinbaugh, M. G., Willie, K. J., Reed, S., Goodin, M., and Hogenhout, S. A. (2005). Complete genome sequence and in planta subcellular localization of maize fine streak virus proteins. J. Virol. 79, 5304-5314. doi: 10.1128/JVI.79.9.5304-5314.2005 
Ueki, S., Spektor, R., Natale, D. M., and Citovsky, V. (2010). ANK, a host cytoplasmic receptor for the tobacco mosaic virus cell-to-cell movement protein, facilitates intercellular transport through plasmodesmata. PLoS Pathog. 6:e1001201. doi: 10.1371/journal.ppat.1001201

van Lent, J., Storms, M., Van Der Meer, F., Wellink, J., and Goldbach, R. (1991) Tubular structures involved in movement of cowpea mosaic virus are also formed in infected cowpea protoplasts. J. Gen. Virol. 72, 2615-2623. doi: 10.1099/00221317-72-11-2615

Voinnet, O., Pinto, Y. M., and Baulcombe, D. C. (1999). Suppression of gene silencing: a general strategy used by diverse DNA and RNA viruses of plants. Proc. Natl. Acad. Sci. U.S.A. 96, 14147-14152. doi: 10.1073/pnas.96.24.14147

Waigmann, E., Ueki, S., Trutnyeva, K., and Citovsky, V. (2004). The ins and outs of nondestructive cell-to-cell and systemic movement of plant viruses. Crit. Rev. Plant Sci. 23, 195-250. doi: 10.1080/07352680490452807

Wei, T., Kikuchi, A., Moriyasu, Y., Suzuki, N., Shimizu, T., Hagiwara, K., et al. (2006). The spread of rice dwarf virus among cells of its insect vector exploits virus-induced tubular structures. J. Virol. 80, 8593-8602. doi: 10.1128/JVI. 00537-06

Wei, T., Shimizu, T., and Omura, T. (2008). Endomembranes and myosin mediate assembly into tubules of Pns10 of rice dwarf virus and intercellular spreading of the virus in cultured insect vector cells. Virology 372, 349-356. doi: 10.1016/j.virol.2007.10.034

Wetzel, T., Dietzgen, R. G., and Dale, J. L. (1994). Genomic organization of lettuce necrotic yellows rhabdovirus. Virology 200, 401-412. doi: 10.1006/viro. 1994.1204

Wu, Z., Wu, J., Adkins, S., Xie, L., and Li, W. (2010). Rice ragged stunt virus segment S6-encoded nonstructural protein Pns6 complements cell-to-cell movement of tobacco mosaic virus-based chimeric virus. Virus Res. 152, 176-179. doi: 10.1016/j.virusres.2010.06.003

Xiong, R., Wu, J., Zhou, Y., and Zhou, X. (2008). Identification of a movement protein of the tenuivirus rice stripe virus. J. Virol. 82, 12304-12311. doi: 10.1128/JVI.01696-08

Yassi, M. N. A., Ritzenthaler, C., Brugidou, C., Fauquet, C., and Beachy, R. N. (1994). Nucleotide sequence and genome characterization of rice yellow mottle virus RNA. J. Gen. Virol. 75, 249-257. doi: 10.1099/0022-1317-75-2-249
You, Y., and Shirako, Y. (2010). Bymovirus reserve genetics: requirements for RNA2encoded proteins in systemic infection. Mol. Plant Pathol. 11, 383-394. doi: 10.1111/j.1364-3703.2010.00613.x

Yuan, Z., Chen, H., Chen, Q., Omura, T., Xie, L., Wu, Z., et al. (2011). The early secretory pathway and an actin-myosin VIII motility system are required for plasmodesmatal localization of the NSvc4 protein of rice stripe virus. Virus Res. 159, 62-68. doi: 10.1016/j.virusres.2011.04.023

Zhang, C., Pei, X., Wang, Z., Jia, S., Guo, S., Zhang, Y., et al. (2012). The rice stripe virus pc4 functions in movement and foliar necrosis expression in Nicotiana benthamiana. Virology 425, 113-121. doi: 10.1016/j.virol.2012. 01.007

Zheng, H., Wang, G., and Zhang, L. (1997). Alfalfa mosaic virus movement protein induces tubules in plant protoplasts. Mol. Plant Microbe Interact. 10, 1010-1014. doi: 10.1094/MPMI.1997.10.8.1010

Zhou, G., Wen, J., Cai, D., Li, P., Xu, D., and Zhang, S. (2008). Southern rice black-streaked dwarf virus: a new proposed Fijivirus species in the family Reoviridae. Chin. Sci. Bull. 53, 3677-3685. doi: 10.1007/s11434-0080467-2

Conflict of Interest Statement: The authors declare that the research was conducted in the absence of any commercial or financial relationships that could be construed as a potential conflict of interest.

Received: 13 September 2013; accepted: 20 April 2014; published online: 20 May 2014 Citation: Hiraguri A, Netsu O, Sasaki N, Nyunoya H and Sasaya T (2014) Recent progress in research on cell-to-cell movement of rice viruses. Front. Microbiol. 5:210. doi: $10.3389 /$ fmicb.2014.00210

This article was submitted to Virology, a section of the journal Frontiers in Microbiology. Copyright (C) 2014 Hiraguri, Netsu, Sasaki, Nyunoya and Sasaya. This is an openaccess article distributed under the terms of the Creative Commons Attribution License (CC BY). The use, distribution or reproduction in other forums is permitted, provided the original author(s) or licensor are credited and that the original publication in this journal is cited, in accordance with accepted academic practice. No use, distribution or reproduction is permitted which does not comply with these terms. 